\title{
PENERAPAN METODE ANALYTIC HIERARCHY PROCESS (AHP) UNTUK SELEKSI TENAGA AKADEMIK
}

\author{
Farindika Metandi \\ Program Studi Teknik Informatika \\ Politeknik Negeri Samarinda \\ Email:farindika@polnes.ac.id
}

\begin{abstract}
Abstrak - Manajemen sumber daya pengajar (Calon tenaga akademik) merupakan salah satu unsur terpenting dalam lingkungan pendidikan tinggi. Manajemen sumber daya calon tenaga akademik dapat dikelompokkan menjadi empat kegiatan utama, yaitu perencanaan seleksi calon tenaga akademik baru, penilaian selama masa percobaan, perencanaan pengembangan, dan promosi jabatannya. Proses keputusan seleksi dalam kenyataannya melibatkan beberapa kriteria bersifat kualitatif yang ditentukan oleh pengambil keputusan. Sering kali evaluasi dari proses keputusan-keputusan merupakan masalah yang tidak terstruktur. Suatu penggunaan model keputusan multi kriteria banyak diterapkan untuk proses seleksi. Hal ini disebabkan karena proses seleksi merupakan suatu bentuk evaluasi awal yang harus seobjektif mungkin dan memberikan manfaat dengan mengakomodasi multi atribut untuk tujuan organisasi. Metode AHP memungkinkan pengambil keputusan menyatakan interaksi multi faktor dalam situasi yang komplek dan tidak terstruktur. AHP akan menghasilkan urutan ranking prioritas yang mengindikasikan keseluruhan preferensi untuk masing-masing alternatif keputusan. Hasil perhitungan AHP yang diterapkan ini akan menghasilkan keluaran nilai intensitas prioritas Calon tenaga akademik tertinggi sehingga Calon tenaga akademik yang memiliki nilai tertinggi layak untuk diterima.
\end{abstract}

Kata Kunci : Tenaga Akademik, Metode AHP, Keputusan

\section{PENDAHULUAN}

Manajemen sumber daya pengajar (Calon tenaga akademik) merupakan salah satu unsur terpenting dalam lingkungan pendidikan tinggi. Manajemen sumber daya calon tenaga akademik dapat dikelompokkan menjadi empat kegiatan utama, yaitu perencanaan seleksi calon tenaga akademik baru, penilaian selama masa percobaan, perencanaan pengembangan, dan promosi jabatannya. Keempat kegiatan tersebut perlu dilakukan secara simultan dan berkesinambungan agar dapat diperoleh manfaat bersama untuk dua sisi, yaitu para calon tenaga akademik sebagai pribadi dan lembaga pendidikan tinggi sebagai suatu sistem pendidikan. Sebagai pribadi, kegiatan-kegiatan tersebut akan memacu para calon tenaga akademik dalam meningkatkan profesionalismenya sebagai tenaga akademik (peningkatan golongan dan jabatan akademik). Efek dari profesionalisme tersebut akan berimbas pada peningkatan status akreditasi Jurusan.

Proses keputusan seleksi dalam kenyataannya melibatkan beberapa kriteria bersifat kualitatif yang ditentukan oleh pengambil keputusan. Sering kali evaluasi dari proses keputusan-keputusan merupakan masalah yang tidak terstruktur. Hal ini disebabkan oleh hal-hal sebagai berikut :

1. Kurangnya informasi yang lengkap mengenai kebutuhan dan ketersediaan tenaga kerja pada suatu lingkungan yang bersifat dinamis dan tidak pasti.
2. Sedikitnya ketersediaan data kuantitatif yang disebabkan karena sistem tersebut masih dalam tahap perkembangan dan pembelajaran.

3. Adanya multi atribut yang terlibat dalam keputusan evaluasi, dimana seringkali saling konflik dan kadang-kadang saling melengkapi. Yang lebih menyulitkan, atribut yang demikian tersebut tidak dapat dinyatakan dalam satuan unit pengukuran yang umum dan beberapa atribut merefleksikan aspek-aspek psikologis seperti pertimbangan-pertimbangan kualitatif.

Suatu penggunaan model keputusan multi kriteria banyak diterapkan untuk proses seleksi. Hal ini disebabkan karena proses seleksi merupakan suatu bentuk evaluasi awal yang harus seobjektif mungkin dan memberikan manfaat dengan mengakomodasi multi atribut untuk tujuan organisasi. Dengan kata lain, proses seleksi yang diikuti oleh penilaian personil selama masa uji coba, pengembangan personil dan perencanaan karir harus memberikan manfaat dengan menempatkan orang yang tepat, pada tempat yang tepat, pada pekerjaan yang tepat, pada waktu yang tepat, dan dengan biaya yang tepat. Masalah model keputusan multi kriteria mempunyai beberapa elemen khusus sebagai berikut:

- Pernyataan dari masalah 
- Suatu set dari alternatif yang layak

- Suatu set kriteria

- Suatu skala estimasi

- Suatu pemetaan dari alternatif fisibel dengan skala estimasinya

- Sistem preferensi dari pengambil keputusan

- Aturan keputusan

Metode AHP memungkinkan pengambil keputusan menyatakan interaksi multi faktor dalam situasi yang komplek dan tidak terstruktur. Proses dalam metode ini mengharuskan pengambil keputusan untuk mengembangkan struktur hirarki (berjenjang untuk faktor-faktor yang secara eksplisit diberikan pada masalah yang diberikan dan menentukan keputusan tentang kepentingan relatif dari masing-masing faktor terhadap faktor lainnya, dimana hasil akhirnya adalah untuk menentukan preferensi dari masing-masing alternatif keputusan. AHP akan menghasilkan urutan ranking prioritas yang mengindikasikan keseluruhan preferensi untuk masing-masing alternatif keputusan. Keunggulan AHP dibandingkan model keputusan banyak kriteria, misalkan keputusan multi objektif, adalah bahwa AHP didesain untuk memasukkan faktor-faktor tangiabel sebagaimana faktor-faktor non-tangiabel, khususnya pada kondisi dimana pendapat subjektif dari individu-individu yang berbeda merupakan bagian penting dari proses keputusan. Ketika membentuk hirarki, pengambil keputusan perlu memasukkan detail-detail faktor dan atribut yang relevan dalam menyatakan masalah selengkap mungkin.

Pendekatan umum AHP adalah mendekomposisi seluruh masalah menjadi sub masalah yang lebih kecil sehingga masing-masing sub masalah tersebut dapat dianalisa dan diselesaikan secara tepat berdasarkan data dan informasi yang praktis. Tujuan dari pendekomposisian seluruh masalah menjadi beberapa tingkatan adalah untuk mencari perbandingan berpasangan seluruh elemen yang berhubungan. Proses penyelesaian secara AHP terdiri dari tiga tahapan

1. Penentuan derajat kepentingan masing-masing atribut

2. Penentuan derajat kepentingan dari masingmasing alternatif dalam hubungannya dengan masing- masing atribut

3. Penentuan prioritas bobot keseluruhan untuk masing-masing alternatif

Untuk menggambarkan mekanisme kerja model AHP, anggaplah ada satu masalah sederhana dari evaluasi seleksi yang melibatkan tiga kandidat (A, B, dan C) yang akan dievaluasi dalam beberapa kriteria. Gambar 1 menunjukkan skema format dari contoh masalah hirarki, dimana pada level pertama merupakan keseluruhan tujuan untuk menilai kandidat terbaik yang ada. Level kedua menunjukkan beberapa kriteria seperti kemampuan, pengetahuan, motivasi, dan kepribadian yang akan menentukan hasil dari tujuan keseluruhan pada level pertama. Level ketiga menunjukkan bahwa kita mempunyai sub kriteria untuk masing-masing kriteria pada 1 pada level kedua, yaitu : intelegensi, riset, dan eksplanasi untuk kemampuan, dan bidang utama serta bidang penunjang untuk kriteria pengetahuan. Level keempat menunjukkan bahwa kita mempunyai tiga alternatif kandidat (A, B, C) yang perlu dievaluasi seleksinya berdasarkan kriteria yang telah ditetapkan. Gambar 1 menunjukkan struktur model AHP yang meliputi tujuan dan criteria-kriteria yang digunakan untuk evaluasi seleksi.

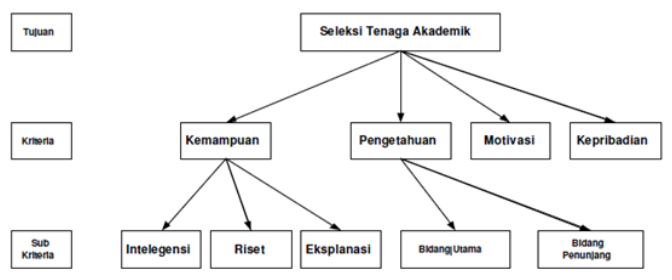

Gambar 1. Struktur Hirarki AHP Model Seleksi Tenaga Akademik

\section{TINJAUAN PUSTAKA}

\subsection{Decision Support System}

Decision Support System (DSS) atau Sistem Pendukung Keputusan (SPK) adalah pemilihan beberapa tindakan alternatif yang ada untuk mencapai satu atau beberapa tujuan yang telah ditetapkan. Sistem Pendukung Keputusan adalah suatu sistem berbasis komputer yang menghasilkan berbagai alternatif keputusan untuk membantu manajemen dalam menangani berbagai permasalahan yang terstruktur ataupun tidak terstruktur dengan menggunakan data dan model. Komponen DSS dapat dilihat pada Gambar 2.

1. Subsistem Manajemen Data (Data Management Subsystem).

2. Subsistem Manajemen Model (Model Management Subsystem).

3. Subsistem Manajemen Pengetahuan (Knowledge Management Subsystem).

4. Subsistem Antarmuka Pengguna (User Interface Subsystem).

5. Pengguna (user), termasuk di dalamnya adalah pengguna (user), manager, dan pengambil keputusan. 


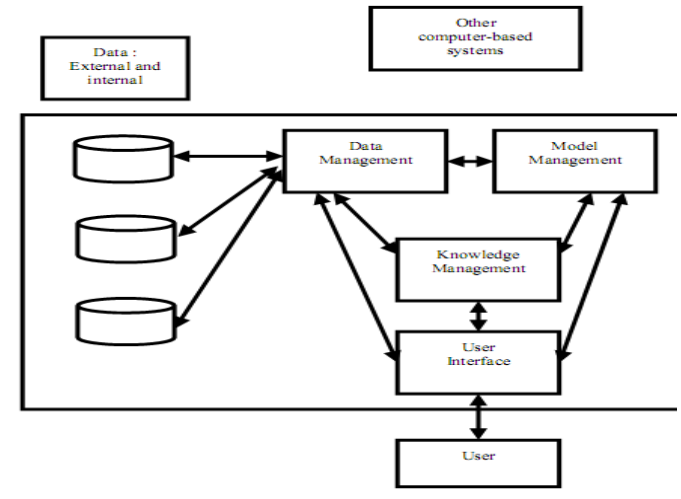

Gambar 2. Komponen-komponen DSS

\subsection{Analytic Hierarchy Process (AHP)}

Pada hakekatnya AHP merupakan suatu model pengambil keputusan yang komprehensif dengan memperhitungkan hal- hal yang bersifat kualitatif dan kuantitatif. Dalam model pengambilan keputusan dengan AHP pada dasarnya berusaha menutupi semua kekurangan dari model-model sebelumnya. AHP juga memungkinkan ke struktur suatu sistem dan lingkungan kedalam komponen saling berinteraksi dan kemudian menyatukan mereka dengan mengukur dan mengatur dampak dari komponen kesalahan sistem [1].

Prinsip kerja AHP adalah penyederhanaan suatu persoalan kompleks yang tidak terstruktur, stratejik, dan dinamik menjadi bagian-bagiannya, serta menata dalam suatu hierarki. Kemudian tingkat kepentingan setiap variabel diberi nilai numerik secara subjektif tentang arti penting variabel tersebut secara relatif dibandingkan dengan variabel lain. Dari berbagai pertimbangan tersebut kemudian dilakukan sintesa untuk menetapkan variabel yang memiliki prioritas tinggi dan berperan untuk mempengaruhi hasil pada sistem tersebut [2].

Pada dasarnya langkah-langkah dalam metode AHP meliputi :

1. Menyusun hirarki dari permasalahan yang dihadapi.

Persoalan yang akan diselesaikan, diuraikan menjadi unsur-unsurnya, yaitu kriteria dan alternatif, kemudian disusun menjadi struktur hierarki seperti Gambar 3.

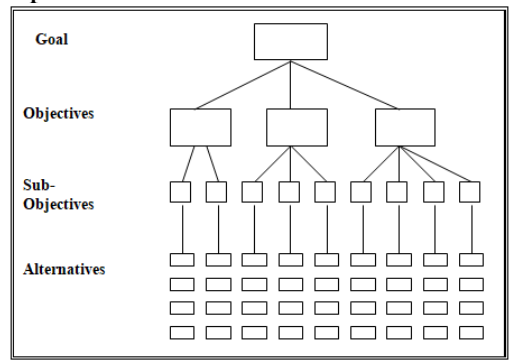

Gambar 3 Struktur Hierarki AHP
2. Penilaian kriteria dan alternatif

Kriteria dan alternatif dinilai melalui perbandingan berpasangan. Untuk berbagai persoalan, skala 1 sampai 9 adalah skala terbaik dalam mengekspresikan pendapat. Nilai dan definisi pendapat kualitatif dari skala perbandingan Saaty dapat dilihat pada Tabel 1 [3].

Tabel 1. Skala Penilaian Perbandingan Berpasangan

\begin{tabular}{|c|l|}
\hline $\begin{array}{c}\text { Intensitas } \\
\text { Kepentingan }\end{array}$ & \multicolumn{1}{|c|}{ Keterangan } \\
\hline 1 & Kedua elemen sama pentingnya \\
\hline 3 & $\begin{array}{l}\text { Elemen yang satu sedikit lebih penting } \\
\text { daripada elemen yang lainnya }\end{array}$ \\
\hline 5 & $\begin{array}{l}\text { Elemen yang satu lebih penting daripada yang } \\
\text { lainnya }\end{array}$ \\
\hline 7 & $\begin{array}{l}\text { Satu elemen jelas lebih mutlak penting } \\
\text { daripada elemen lainnya }\end{array}$ \\
\hline 9 & $\begin{array}{l}\text { Satu elemen mutlak penting daripada elemen } \\
\text { lainnya }\end{array}$ \\
\hline $2,4,6,8$ & $\begin{array}{l}\text { Nilai-nilai antara dua nilai pertimbangan- } \\
\text { pertimbangan yang berdekatan }\end{array}$ \\
\hline
\end{tabular}

Perbandingan dilakukan berdasarkan kebijakan pembuat keputusan dengan menilai tingkat kepentingan satu elemen terhadap elemen lainnya Proses perbandingan berpasangan, dimulai dari level hirarki paling atas yang ditujukan untuk memilih kriteria, misalnya A, kemudian diambil elemen yang akan dibandingkan, misal A1, A2, dan A3. Maka susunan elemen-elemen yang dibandingkan tersebut akan tampak seperti pada gambar matriks di Tabel 2.

Tabel 2. Contoh matriks perbandingan berpasangan

\begin{tabular}{|c|c|c|c|}
\hline & A1 & A2 & A3 \\
\hline A1 & 1 & & \\
\hline A2 & & 1 & \\
\hline A3 & & & 1 \\
\hline
\end{tabular}

3. Penentuan prioritas

Untuk setiap kriteria dan alternatif, perlu dilakukan perbandingan berpasangan (pairwise comparisons). Nilai-nilai perbandingan relatif kemudian diolah untuk menentukan peringkat alternatif dari seluruh alternatif.

Baik kriteria kualitatif, maupun kriteria kuantitatif, dapat dibandingkan sesuai dengan penilaian yang telah ditentukan untuk 
menghasilkan bobot dan proritas. Bobot atau prioritas dihitung dengan manipulasi matriks atau melalui penyelesaian persamaan matematik.

4. Konsistensi Logis

Semua elemen dikelompokkan secara logis dan diperingatkan secara konsisten sesuai dengan suatu kriteria yang logis.

Penghitungan konsistensi logis dilakukan dengan mengikuti langkah-langkah sebagai berikut :

a. Mengalikan matriks dengan proritas bersesuaian.

b. Menjumlahkan hasil perkalian per baris.

c. Hasil penjumlahan tiap baris dibagi prioritas bersangkutan dan hasilnya dijumlahkan.

d. Hasil c dibagi jumlah elemen, akan didapat $\lambda$ maks.

e. Indeks Konsistensi $(\mathrm{CI})=(\lambda$ maks-n) $/(n-$ 1)

f. Rasio Konsistensi = CI/ RI, di mana RI adalah indeks random konsistensi. Jika rasio konsistensi $=0.1$, hasil perhitungan data dapat dibenarkan.

Daftar RI dapat dilihat pada Tabel 3.

Tabel 3. Nilai Indeks Random

\begin{tabular}{|c|c|}
\hline Ukuran Matriks & Nilai RI \\
\hline 1,2 & 0,00 \\
\hline 3 & 0,58 \\
\hline 4 & 0,90 \\
\hline 5 & 1,12 \\
\hline 6 & 1,24 \\
\hline 7 & 1,32 \\
\hline 8 & 1,41 \\
\hline 9 & 1,45 \\
\hline 10 & 1,49 \\
\hline 11 & 1,51 \\
\hline 12 & 1,48 \\
\hline 13 & 1,56 \\
\hline 14 & 1,57 \\
\hline 15 & 1,59 \\
\hline
\end{tabular}

\section{DESAIN DAN PERANCANGAN}

\subsection{Tahap-Tahap Perancangan}

Sesuai dengan kebutuhan dalam penelitian ini tahap-tahap kegiatannya adalah sebagai berikut :

1. Menentukan kriteria-kriteria yang diperlukan (ada 4 kriteria) menggunakan matriks berpasangan. Dicontohkan pada Tabel 4.

Tabel 4. Matriks Berpasangan 4 Jenis Kriteria

\begin{tabular}{|l|l|l|l|l|}
\hline & Pengetahuan & Kreativitas & Motivasi & Kepribadian \\
\hline Pengetahuan & & & & \\
\hline Kreativitas & & & & \\
\hline Motivasi & & & & \\
\hline Kepribadian & & & & \\
\hline
\end{tabular}

2. Menentukan nama-nama Calon tenaga akademik yang sebelumnya sudah diperkirakan memiliki prestasi kerja yang baik.

3. Menjumlah setiap kolom pada Tabel 4.

4. Menentukan nilai elemen kolom kriteria dengan rumus : tiap-tiap sel pada Tabel 4 dibagi dengan masing-masing jumlah kolom pada langkah 3 .

5. Menentukan Prioritas Kriteria pada masingmasing baris pada Tabel 4 dengan rumus jumlah baris dibagi banyak kriteria.

6. Memasukkan data-data nama calon tenaga akademik dalam bentuk matriks berpasangan. Bentuk matriks nama calon Tenaga akademik berpasangan tersebut ditampilkan seperti Tabel 5 .

Tabel 5. Calon Tenaga Akademik
\begin{tabular}{|c|c|c|c|}
\hline & Calon 1 & Calon 2 & Calon 3 \\
\hline Calon 1 & & & \\
\hline Calon 2 & & & \\
\hline Calon 3 & & & \\
\hline
\end{tabular}

7. Menjumlah setiap kolom pada Tabel 5.

8. Menentukan nilai elemen kolom nama dengan rumus : tiap-tiap sel pada Tabel 5 dibagi masingmasing jumlah kolom.

9. Menentukan Prioritas Calon pada masing-masing baris pada Tabel 5 dengan rumus jumlah baris dibagi banyak calon

10. Mengukur konsistensi, yaitu menguji konsistensi.

11. Menghitung $\lambda \max , \mathrm{CI}$, dan $\mathrm{CR}$.

12. Menghitung prioritas global.

\section{HASIL DAN PEMBAHASAN}

Sesuai dengan langkah-langkah penelitian pada bab III, pada bab IV ini akan dibahas tentang masukan data yang sebenarnya, proses perhitungan dan keluaran yang diharapkan untuk studi kasus seleksi tenaga akademik. Masukan awal adalah menentukan nilai kriteria dimisalkan seperti Tabel 6 .

Tabel 6. Menentukan Nilai Kriteria

\begin{tabular}{|l|c|c|c|c|}
\hline & Pengetahuan & Kreativitas & Motivasi & Kepribadian \\
\hline Pengetahuan & 1 & 3 & 2 & 3 \\
\hline Kreativitas & 0.33333333 & 1 & 3 & 3 \\
\hline Motivasi & 0.5 & 0.33333333 & 1 & 2 \\
\hline Kepribadian & 0.33333333 & 0.3333333 & 0.5 & 1 \\
\hline
\end{tabular}


Setelah masukan data Tabel 6, dihasilkan nilai pembagian jumlah kolom yang rumusnya adalah masing-masing sel pada Tabel 6 dibagi dengan jumlah kolom masing-masing. Hasilnya ditampilkan pada Tabel 7.

Tabel 7. Hasil Perhitungan Nilai Kriteria
\begin{tabular}{|l|c|c|c|c|c|}
\hline & Pengetahuan & Kreativitas & Motivasi & Kepribadian & Jumlah Baris \\
\hline Pengetahuan & 0.461538462 & 0.642857143 & 0.307692308 & 0.333333333 & 1.745421245 \\
\hline Kreativitas & 0.153846154 & 0.214285714 & 0.461538462 & 0.333333333 & 1.163003663 \\
\hline Motivasi & 0.230769231 & 0.071428571 & 0.153846154 & 0.2222222222 & 0.678266178 \\
\hline Kepribadian & 0.153846154 & 0.071428571 & 0.076923077 & 0.111111111 & 0.413308913 \\
\hline
\end{tabular}

Sedangkan Untuk menghitung Prioritas Kriteria digunakan rumus Jumlah Baris pada Tabel 7 dibagi dengan banyak kriteria. Hasilnya ditampilkan pada Tabel 8.

Tabel 8. Perhitungan Prioritas Kriteria

\begin{tabular}{|l|l|}
\hline Nama Kriteria & Prioritas Kriteria \\
\hline Pengetahuan & 0.436355311 \\
\hline Kreativitas & 0.290750916 \\
\hline Motivasi & 0.169566545 \\
\hline Kepribadian & 0.103327228 \\
\hline
\end{tabular}

Setelah dihasilkan prioritas kriteria, langkah berikutnya menghitung prioritas personal calon dengan memasukkan skor pada masing-masing calon untuk tiap kriteria. Masukan tersebut merupakan pemisalan yang ditampilkan pada Tabel 9 dan Tabel 10. Cara yang sama juga dilakukan untuk kriteria Kreativitas, Motivasi, dan Kepribadian.

Tabel 9. Kriteria Pengetahuan

\begin{tabular}{|c|c|c|c|c|c|c|}
\hline & \multicolumn{2}{|c|}{ Calon 1} & \multicolumn{2}{|c|}{ Calon 2} & \multicolumn{2}{|c|}{ Calon 3} \\
\hline Calon 1 & \multicolumn{2}{|l|}{1} & \multicolumn{2}{|r|}{2} & \multicolumn{2}{|l|}{9} \\
\hline Calon 2 & \multicolumn{2}{|l|}{0.5} & \multicolumn{2}{|r|}{1} & \multicolumn{2}{|l|}{2} \\
\hline Calon 3 & \multicolumn{2}{|c|}{0.111111} & \multicolumn{2}{|r|}{0.5} & \multicolumn{2}{|l|}{1} \\
\hline Jumlah & \multicolumn{2}{|c|}{1.611111} & \multicolumn{2}{|r|}{3.5} & \multicolumn{2}{|l|}{12} \\
\hline \multicolumn{7}{|c|}{ Tabel 10. Kriteria Pengetahuan } \\
\hline & Calon 1 & Calo & & Calon 3 & Jumlah Baris & $\begin{array}{c}\text { Eigenvector } \\
\text { Utama }\end{array}$ \\
\hline Calon 1 & 0.62068966 & 0.571 & & 0.75 & 1.942118227 & 0.647373 \\
\hline Calon 2 & 0.31034483 & 0.285 & & 0.1666667 & 0.76272578 & 0.254242 \\
\hline $\begin{array}{l}\text { Calon } 3 \\
\end{array}$ & 0.06896552 & 0.142 & & 0.0833333 & 0.295155993 & 0.098385 \\
\hline
\end{tabular}

Hasilnya adalah prioritas skor calon Tenaga akademik untuk masing-masing kriteria yang didapat dari pembagian jumlah baris dengan jumlah Calon tenaga akademik yang dinilai (disebut juga dengan eigen vector utama). Hasil tersebut ditampilkan pada Tabel 11.

Tabel 11. Prioritas Skor Calon Tenaga Akademik

\begin{tabular}{|l|c|c|c|c|}
\hline Nama & Pengetahuan & Kreativitas & Motivasi & Kepribadian \\
\hline Calon 1 & 0.647373 & 0.588889 & 0.490476 & 0.137288 \\
\hline Calon 2 & 0.254242 & 0.251852 & 0.311905 & 0.623225 \\
\hline Calon 3 & 0.098385 & 0.159259 & 0.197619 & 0.239488 \\
\hline
\end{tabular}

Selanjutnya adalah menilai konsistensi dari masing-masing penilaian baik terhadap prioritas kriteria, maupun terhadap calon Tenaga akademik untuk tiap krtiteria.

Nilai eigen terbesar didapat dengan menjumlahkan hasil perkalian jumlah kolom dengan eigen vektor utama. Sebagai contoh, menggunakan Tabel 9 dan Tabel 10, nilai eigen terbesar yang diperoleh: $\lambda$ maks $=1.611111 * 0.647373+3.5 * 0.254242+12 * 0.098385$ $=3.1134601$

Karena matrix berordo 3 (yakni terdiri dari 3 faktor), nilai indek konsistensi yang diperoleh:

$$
C . I=\frac{3.1134601-3}{3-1}=0.0567301
$$

Apabila C.I bernilai nol, berarti matrik konsisten. Batas ketidakkonsistensi yang ditetapkan Saaty, diukur dengan menggunakan Rasio Konsistensi (CR), yakni perbandingan indeks konsistensi dengan nilai pembangkit random (RI) seperti ditampilkan pada tabel 3.

Melanjutkan perhitungan tabel 9 dan 10 tadi, maka didapat

$$
C R=\frac{0.0567301}{0.58}=0.0978105 .
$$

Karena $C R<0,1$ maka nilai perbandingan berpasangan pada matriks kriteria yang diberikan konsisten. Jika CR tidak < 0.1 , maka perlu diadakan kembali penilaian dengan menggunakan matriks berpasangan.

Selanjutnya adalah menghitung nilai kriteria tiap-tiap calon Tenaga akademik untuk masingmasing item kriteria dengan rumus matriks pada Tabel 11 dikalikan dengan matriks pada Tabel 8 . Hasilnya ditampilkan pada Tabel 12.

Tabel 12. Nilai Kriteria Calon Tenaga Akademik

\begin{tabular}{|l|c|c|c|c|}
\hline Nama & Pengetahuan & Kreativitas & Motivasi & Kepribadian \\
\hline Calon 1 & 0.282484647 & 0.171220016 & 0.08316832 & 0.0141856 \\
\hline Calon 2 & 0.110939847 & 0.0732262 & 0.05288865 & 0.0643961 \\
\hline Calon 3 & 0.042930817 & 0.0463047 & 0.03350957 & 0.0247456 \\
\hline
\end{tabular}

Kemudian dicari nilai prioritas global untuk masing-masing calon Tenaga akademik yaitu dengan menjumlahkan baris pada Tabel 12. Hasil prioritas global diperlihatkan pada tabel 13.

Tabel 13. Nilai Prioritas Global

\begin{tabular}{|l|c|}
\hline Nama & Prioritas Global \\
\hline Calon 1 & 0.551058572 \\
\hline Calon 2 & 0.301450812 \\
\hline Calon 3 & 0.14749072 \\
\hline
\end{tabular}

Dari prioritas global pada Tabel 13 dapat diketahui bahwa nilai terbesar adalah Calon 1 yaitu 0.551058572, maka Calon 1 merupakan Calon tenaga akademik yang pantas diterima dari hasil seleksi.

\section{KESIMPULAN}

Adapun kesimpulan-kesimpulan yang didapatkan dalam penulisan ini:

1. Telah dapat dibangun suatu system pengambilan keputusan dengan menggunakan metode AHP untuk seleksi tenaga akademik.

2. Interval bobot yang dipakai dalam penilaian Calon tenaga akademik ini adalah 0-4, dimana 0 adalah buruk, 1 adalah kurang dari cukup, 2 adalah cukup, 3 adalah baik, dan 4 adalah sangat baik. Semakin tinggi nilai bobot penilaian 
dokumen maka semakin tinggi pula nilai intensitas total penilaian Calon tenaga akademik.

3. Hasil perhitungan AHP yang diterapkan ini akan menghasilkan keluaran nilai intensitas prioritas Calon tenaga akademik tertinggi sehingga Calon tenaga akademik yang memiliki nilai tertinggi layak untuk diterima.

\section{DAFTAR PUSTAKA}

[1] Saaty, T.L. 1988. Multicriteria Decision Making : The Analytic Hierarchy Process. University of Pittsburgh, RWS Publication, Pittsburgh.

[2] Marimin. 2004. Teknik dan Aplikasi Pengambilan Keputusan Kriteria Majemuk. Penerbit PT Grasindo, Jakarta.
[3] Saaty, T.L.1988. Multicriteria Decision Making: The Analytic Hierarchy Process. University of Pittsburgh, RWS Publication, Pittsburgh 